\title{
Impact of legislation and public funding on oncofertility: a survey of Canadian, French and Moroccan pediatric hematologists/ oncologists
}

\author{
Aliya Oulaya Affdal ${ }^{1,2^{*}}$, Michael Grynberg ${ }^{3}$, Laila Hessissen ${ }^{4}$ and Vardit Ravitsky ${ }^{1,2}$
}

\begin{abstract}
Background: Chemotherapy and/or radiotherapy treatments may cause premature ovarian failure and irreversible loss of fertility. In the context of childhood cancers, it is now acknowledged that possible negative effects of therapies on future reproductive autonomy are a major concern. While a few options are open to post-pubertal patients, the only immediate option currently open to pre-pubertal girls is cryopreservation of ovarian tissue and subsequent transplantation. The aim of the study was to address a current gap in knowledge regarding the offer of fertility preservation by Ovarian Tissue Cryopreservation (OTC) for prepubescent girls with cancer, and to explore current practices and attitudes of Canadian, French and Moroccan pediatric heme oncologists. The comparative perspective is relevant since legal frameworks surrounding fertility preservation and funding offered by the healthcare system vary greatly.
\end{abstract}

Methods: An online survey was sent to the 45 pediatric oncology centers in Canada, France and Morocco.

Results: A total of 39 centers responded (86.6\%). OTC is offered by almost all pediatric heme oncologists in France (98\%), very few in Canada (5\%), and none in Morocco (0\%). For pediatric hematologists/oncologists who do not propose fertility preservation in Canada, the reasons are: the technique is still experimental (54\%), it is not available locally (26\%) and cost of the technique for the family (14\%). 97\% of Canadian and 100\% of Moroccan pediatric hematologists/oncologists think OTC should be funded by the healthcare system as it is in France and in the province of Quebec in Canada.

Conclusions: The results of this study show tremendous diversity in the provision of OTC across countries, whereby its offer is correlated with legislation and funding. We argue that the current reality, in which this technology is often not offered to families, raises ethical issues related to justice and equity of access, as well as informed consent and future reproductive autonomy.

\footnotetext{
* Correspondence: affdal-aliya@orange.fr

${ }^{1}$ Bioethics Program, Department of Social and Preventive Medicine, School of

Public Health, University of Montreal, Montréal, Québec, Canada

${ }^{2}$ Centre de Recherche en Santé Publique, Montreal, Québec, Canada

Full list of author information is available at the end of the article
}

C The Author(s). 2020 Open Access This article is licensed under a Creative Commons Attribution 4.0 International License, which permits use, sharing, adaptation, distribution and reproduction in any medium or format, as long as you give appropriate credit to the original author(s) and the source, provide a link to the Creative Commons licence, and indicate if changes were made. The images or other third party material in this article are included in the article's Creative Commons licence, unless indicated otherwise in a credit line to the material. If material is not included in the article's Creative Commons licence and your intended use is not permitted by statutory regulation or exceeds the permitted use, you will need to obtain permission directly from the copyright holder. To view a copy of this licence, visit http://creativecommons.org/licenses/by/4.0/. The Creative Commons Public Domain Dedication waiver (http://creativecommons.org/publicdomain/zero/1.0/) applies to the data made available in this article, unless otherwise stated in a credit line to the data. 


\section{Background}

Chemotherapy and radiotherapy treatments have increased the life expectancy of cancer patients. However, depending on their aggressiveness, these treatments may cause premature ovarian failure and irreversible loss of fertility [1]. In the context of childhood cancers, it is now acknowledged that possible negative effects of therapies on future reproductive autonomy are a major concern [2, 3]. While a few options are available to post-pubertal patients (such as oocyte or embryo cryopreservation), the only immediate alternative for pre-pubertal girls is ovarian tissue cryopreservation (OTC) with subsequent transplantation, a procedure that is still experimental $[4,5]$. The American Society of Clinical Oncology and National Comprehensive Cancer Network guidelines state that OTC is an investigational method of fertility preservation and the possibility of reseeding cancer through transplanted tissue exists [6-8]. Nevertheless, it already resulted in the birth of over 130 babies, 2 of them born from ovarian tissue that has been cryopreserved in childhood [9-11].

In 2013 and 2018, the American Society of Clinical Oncology (ASCO) recommended that patients be fully informed about the risk of infertility and fertility preservation options prior to cancer treatment [12] but it remains unclear how this guidance should be implemented in practice. Several studies concerning practices of pediatric hematologists/oncologists regarding fertility preservation in pre-pubertal girls have been recently published regarding the US $[13,14]$ and some European countries [15-19], but to our knowledge none is available regarding Canada, France and Morocco.

Our study aimed to address this gap and explore health professionals' current practices and attitudes regarding OTC in these countries. The comparative perspective is relevant since legal frameworks surrounding fertility preservation and funding offered by the healthcare system vary greatly. In France, the 2004 Bioethics Law (august 6 - Article L.2141-11) requires offering fertility preservation for cancer patients while in Canada and Morocco there is no such legal recommendation. France offers funding by the healthcare system for fertility preservation for cancer patients, while in Canada (except in the province of Quebec) and Morocco no such funding exists.

\section{Methods}

The survey was conducted in three countries: Canada, France and Morocco. Forty-five centers were identified through the "C17 Council, Canadian Centres Battling Cancer and Blood Disorders in Children" in Canada, the "French National Cancer Institute" in France and the "Moroccan Society of Pediatric Hematology and Oncology" in Morocco. A standardized email introducing the aims of the study was sent to a total of 260 pediatric hematologists/oncologists with a link to an internet- based
English and French survey. Contact data was obtained from the centers' websites.

The survey instrument (Additional file 1) was developed based on a review of the literature and designed to be brief and easy to read, so that physicians would be able to complete it in less than $10 \mathrm{~min}$. The survey included questions on demographic characteristics, questions regarding knowledge of OTC, questions on who is in charge of providing counseling and on public funding by the healthcare system. Open questions were included to seek views regarding the reasons of not providing fertility preservation and the ethical issues associated with OTC. The survey also provided a free text space for participants to add any comments on the topic.

The survey was piloted on two pediatric hematologists/ oncologists and two researchers to ensure readability. To increase the return rate, participants were reminded of the survey up to three times. Data was collected between February 2016 and June 2016.

Descriptive statistics were conducted to facilitate statistical analysis. Answers to questions were coded thanks to numerical values. Survey responses were exported to and graphics generated with Microsoft Excel software and SPSS for Mac version 25. Participants' answers are presented as percentages. Qualitative data was exported to the software Nvivo to be examined and coded using thematic content analysis.

We received ethics approval for the study from the institutional review board of the University of Montréal (CÉRES) in Canada (\#15-131-CERES-D). The Ethics Committee of Ibn Sina University Hospital Rabat Centre in Morocco and the Ethics Committee "CPP IDF IV" at the hospital Saint Louis in Paris waived the necessity for ethical approval because the research was not a biomedical research related to health or medical issues and an ethical approval was already obtained in Canada.

All potential participants in this study were sent an email explaining the context, objectives, methodology and expected outcomes of the study, as well as the scientific utility of their participation and a link to the survey. By clicking on the link, a "Procedure for free and informed consent" was presented with full information about the research team, study objectives and protocol. They were also informed about possible benefits of the study, as well as their right to decline the invitation and to withdraw from the study at any time. No specific risks were identified. Participants were informed that returning a completed questionnaire constituted consent to participate in the study.

\section{Results}

Table 1 outlines the detailed demographics characteristics as reported by 96 respondents, representing almost $37 \%$ of the 260 pediatric hematologists/oncologists contacted from Canada, France and Morocco. Forty-five 
Table 1 Demographics of participants

\begin{tabular}{|c|c|c|}
\hline Demographics & $\begin{array}{l}\text { Participants } \\
N(\%)\end{array}$ & $\begin{array}{l}\text { Centers } \\
N(\%)\end{array}$ \\
\hline Total contacted & 260 & 45 \\
\hline Responses received & $96(36.9)$ & $39(86.6)$ \\
\hline Canada & $35(13.5)$ & $12(26.7)$ \\
\hline Ontario & 11 & \\
\hline British Columbia & 7 & \\
\hline Quebec & 4 & \\
\hline Alberta & 3 & \\
\hline Manitoba & 3 & \\
\hline Nova Scotia & 3 & \\
\hline Newfounland & 2 & \\
\hline Saskatchan & 2 & \\
\hline France & $46(17.7)$ & $24(53.3)$ \\
\hline Île-de-France & 13 & \\
\hline Auvergne-Rhône-Alpes & 9 & \\
\hline Grand Est & 4 & \\
\hline Provence-Alpes-Côte d'Azur & 4 & \\
\hline Pays de La Loire & 3 & \\
\hline Région d'outre mer & 3 & \\
\hline Haut de France & 3 & \\
\hline Nouvelle-Aquitaine & 2 & \\
\hline Occitanie & 2 & \\
\hline Bretagne & 1 & \\
\hline Centre-Val de Loire & 1 & \\
\hline Normandie & 1 & \\
\hline Morocco & $10(3.8)$ & $3(6.6)$ \\
\hline Rabat-Salé-Kénitra & 6 & \\
\hline Casablanca-Settat & 3 & \\
\hline Marrakech-Safi & 1 & \\
\hline Not completed or not displayed & $5(1.9)$ & $6(13.3)$ \\
\hline \multicolumn{3}{|l|}{ Gender } \\
\hline Female & $54(56.3)$ & \\
\hline Male & $37(38.5)$ & \\
\hline Not completed or not displayed & $5(5.2)$ & \\
\hline \multicolumn{3}{|c|}{ Years of practice in pediatric oncology unit } \\
\hline$>1$ & $0(0.0)$ & \\
\hline $1-5$ & $15(15.6)$ & \\
\hline $5-10$ & $16(16.7)$ & \\
\hline $10<$ & $60(62.5)$ & \\
\hline Not completed & $5(5.2)$ & \\
\hline
\end{tabular}

pediatric oncology centers were contacted and 39 responded, representing $86,6 \%$.

The results of our study show significant discrepancy in the provision of fertility preservation through OTC across countries. In France, almost all pediatric hematologists/oncologists $(98 \%)$ propose OTC, while very few in Canada (5\%) and none in Morocco (0\%) (Fig. 1). In France, 2 participants from 2 different regions declared not offering OTC. In Canada, 3 participants from 2 different provinces declared offering OTC to their patients.

For pediatric hematologists/oncologists who do not propose fertility preservation, the reasons vary depending on countries. However, two main reasons remain: the technique is still experimental and the cost of the technique for the family (Fig. 2).

Additionally, 97\% of Canadian and 100\% of Moroccan pediatric hematologists/oncologists think that fertility preservation should be funded by the healthcare system to promote equity of access and the quality of life of cancer survivors (Fig. 3).

Cost is indeed an important reason for not offering fertility preservation. For Canadian participants in this study, cost is one of the most important ethical issue raised by OTC. It is cited by only $10 \%$ of Moroccan participants while for French participants the cost is not an ethical issue (Fig. 4).

\section{Discussion}

In France, the offer of fertility preservation is required by a 2004 Bioethics law [20]. Systematic access to fertility preservation is also underlined by the French $\mathrm{Na}$ tional Cancer Plan 2014-2019 [21], which instructs healthcare professionals to inform patients about the fertility risks of cancer treatment and offer them options. For minors, consent should be obtained from parents and the child should be as involved as possible. In contrast to France, in Canada and Morocco there is no legal recommendation to offer fertility preservation (Table 2). These results show that if we consider such offer to be ethically desirable or even required, legislation seems to be an effective method of attaining this objective.

In general, it appears that the offer of OTC for pediatric cancer patients is proportional to the funding. Thus in France, where it is covered by the healthcare system, it is widely offered. Note that in France, this coverage includes the procedure of retrieving ovarian

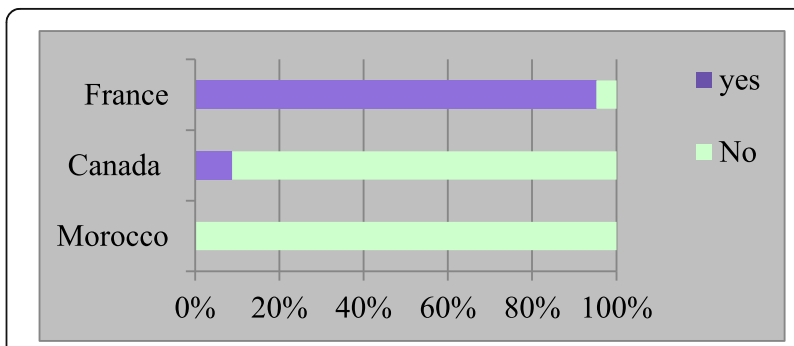

Fig. 1 Do you offer OTC to prepubescent girls? 


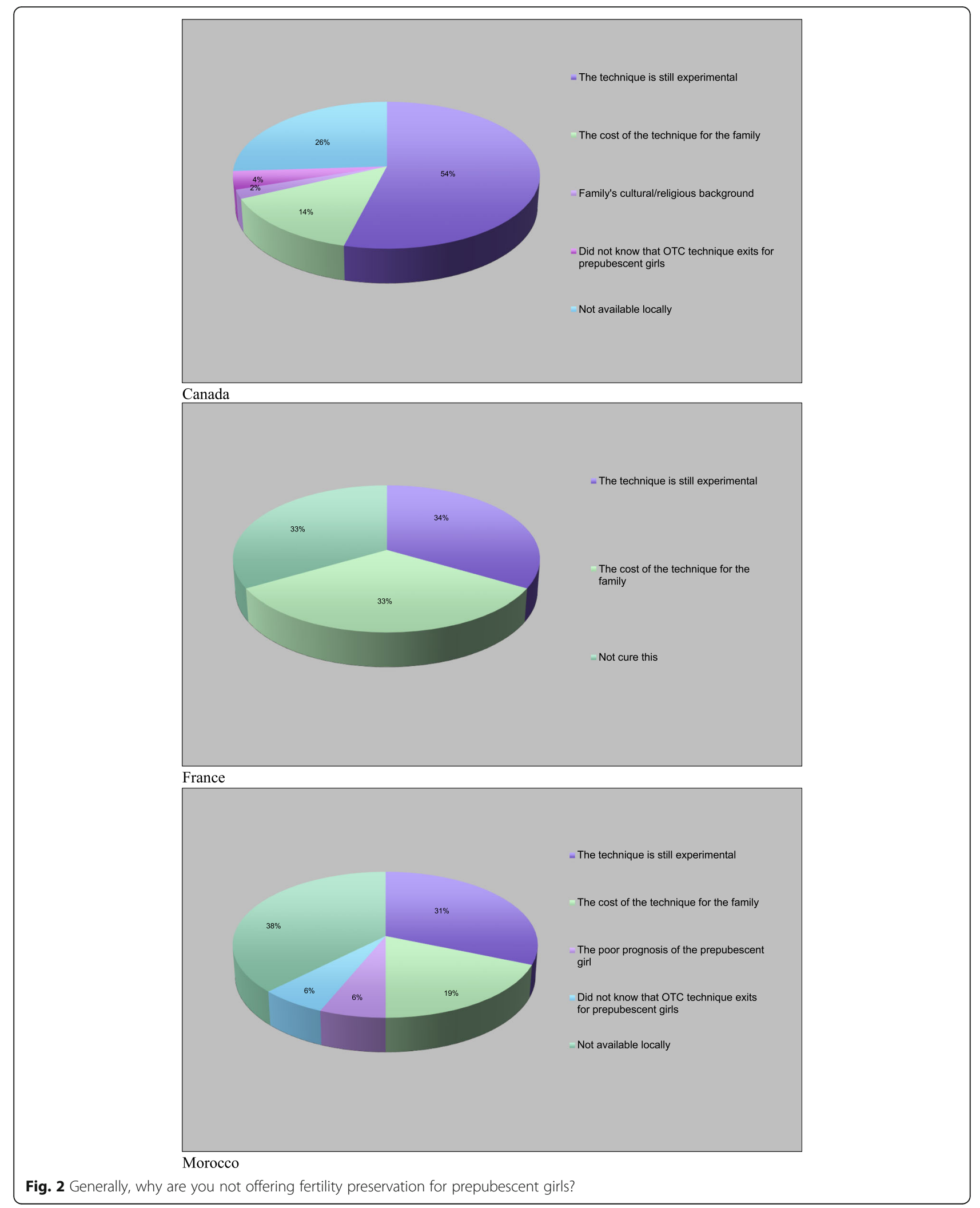




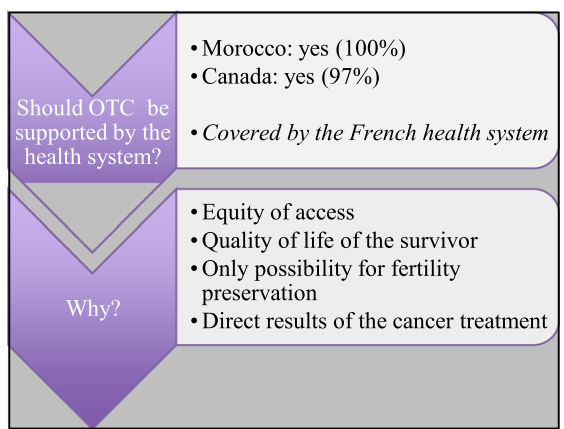

Fig. 3 Fertility preservation for prepubescent girls is covered by France and Quebec's public healthcare system. Do you think that it should be covered by the local healthcare system?

tissue, transplant later in life and IVF, but excludes annual freezing fees [22]. In Morocco, on the other hand, there is no funding by the healthcare system and indeed, none of the Moroccan participants offer OTC (Fig. 1).

In Canada, there is inequality in terms of funding. In Quebec (a Canadian Province in which about 22\% of the Canadian population lives), coverage includes the procedure of retrieving ovarian tissue and freezing fees for 5 years [23] and other provinces offers no funding. Although funding is only available in Quebec, none of the participants from this province offer OTC, which is a surprising finding. Meanwhile, 3 participants from 2 other provinces, where OTC is not covered, do offer it. It is therefore interesting to observe that in Canada, funding does not correlate with offer. This result could be explained by the fact that in Quebec, unlike in France, there is no legal requirement to offer fertility preservation (Table 2). Our findings show that to effectively promote a systematic offer of OTC, both legal requirement and funding are needed.

The funding of fertility preservation for young girls by the French healthcare system - in contrast to Canada (high income) and Morocco (lower middle income) could be explained based on the importance of the principle of vulnerability in European bioethics. Although national health systems and funding policies vary greatly across Europe, some bioethical principles - such as "vulnerability" - are shared by European countries. Some authors have argued that bioethics in Europe has a distinct identity where, contrary to North American bioethics, the principle of vulnerability is paramount [24, 25]. In North America, four principles of biomedical ethics are widely applied and taught in medical schools: autonomy, beneficience, non-maleficience and justice [26], while in Europe, principles of vulnerability, autonomy, dignity and integrity prevail $[24,27]$ (Table 3 ).

The European bioethical principle of vulnerability highlights the "protection of the private sphere of humans beings" [24] and underlines the responsibility of society to protect the most vulnerable persons, such as children. Indeed, children are particularly vulnerable at the time of a life-threatening diagnosis as in the context of oncofertility. This responsibility is highlighted by French respondents who consider the risks associated with the procedure of OTC (risk of pre-menopause due to the removal of the ovary $(27.7 \%)$ and possible risk of reintroducing malignant cells $(13 \%)$ or experimental nature (8.7\%)) as important ethical issues (Fig. 4).

Most participants do not offer OTC as an option because the technique is experimental (Canada, 54\%; France, 34\%; Morocco, 31\%) (Fig. 2). OTC involves extracting and freezing ovarian tissue containing

$\begin{array}{ll}\text { France } & \\ \text { 1. Risk of pre-menopause due to the removal of the ovary } & 27,7 \% \\ \text { 2. Possible risk of reintroducing malignant cells } & 13 \% \\ \text { 3. Experimental nature } & 8.7 \% \\ \text { 4. Cancer prognostic } & 8.7 \% \\ \text { 5. Future reproductive autonomy } & 8.7 \% \\ \text { 6. No guarantee of successful fertility in future } & 6.5 \% \\ & \\ \text { Canada } & \\ \text { 1. Cost } & 20 \% \\ \text { 2. Assent } & 17 \% \\ \text { 3. Posthumous tissue disposition } & 14,3 \% \\ \text { 4. Risks of the procedure } & 14,3 \% \\ \text { 5. Possible delay in treatment } & 14,3 \% \\ \text { 6. No guarantee of successful fertility in future } & 8.5 \% \\ & \\ \text { Morocco } & \\ \text { 1. None } & 30 \% \\ \text { 2. Don't know/No comment } & 20 \% \\ \text { 3. Posthumous use of stored tissue } & 20 \% \\ \text { 4. Cost } & 10 \% \\ \text { 5. No guarantee of successful fertility in future } & 10 \% \\ \text { 6. Availability } & 10 \%\end{array}$

Fig. 4 In your opinion, what are the most important ethical issues of OTC related to fertility preservation in prepubescent girls with cancer? 
Table 2 Legal framework and public funding for fertility preservation for cancer patients

\begin{tabular}{ll}
\hline France & Legal framework \\
Bioethics Law 2004 august 6 - Article \\
"For the subsequent realization of an \\
Reproductive Technology, any person \\
collection and preservation of his gam \\
tissue, when a medical treatment is like \\
when fertility is likely to be premature
\end{tabular}

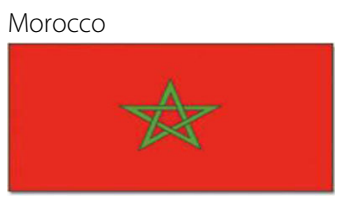

No legal recommendation to offer
Public healthcare system

\author{
Coverage by healthcare system for treatments \\ inducing a loss of fertility \\ Social Security Code - Article D322-1 \\ "The list of conditions involving prolonged treatment \\ and particularly expensive treatment that may give \\ entitlement to withdrawal of the participation of the \\ insured persons (...): malignant tumor, malignant disease \\ of the lymphatic or hematopoietic tissue."
}

\begin{abstract}
No funding by healthcare system, except in the province of Quebec, where the Law 20 Division XII.2 says:

"If rendered to a fertile insured person before any oncological chemotherapy treatment or radiotherapy treatment involving a serious risk of (...) permanent infertility, (...) the fertility preservation services listed below must be considered insured services (...): (a) the services required for ovarian stimulation or ovulation induction;

(b) the services required to retrieve eggs or ovarian tissue; (...)"
\end{abstract}

primordial follicles by laparoscopy before starting oncological treatment $[4,8]$. Since the first OTC performed in 1999 [28], the technique has been increasingly established [29]. In 2012 and 2013, the transplantation of ovarian tissue induced puberty in a 13-year-old girl without the need of hormone treatment [30] and in a 9-yearold girl [31]. This is an important achievement since puberty can be at some points restored naturally without any medical treatment. In 2015 and 2016, this technique resulted in the birth of two children born from ovarian tissue that has been cryopreserved in childhood $[9,10]$ and overall, to date, it resulted in the birth of over 130 babies in women [11].

While it presents certain risks, such as reintroducing malignant cells into the body, which could theoretically propagate cancer recurrence, no study has yet shown such recurrence in humans [29]. Data is also limited regarding livebirth following chemotherapy and OTC without autotransplantation. Indeed, some women might not be sterilized following chemotherapy [32]. Furthermore, as

Table 3 Principles of bioethics

\begin{tabular}{ll}
\hline North American Context & European Context \\
\hline Autonomy & Vulnerability \\
Beneficience & Autonomy \\
Non-maleficience & Dignity \\
Justice & Integrity \\
\hline
\end{tabular}

emphasized by all participants (independently of countries), the absence of guarantee of successful fertility is an important ethical issue (Fig. 4). Proof of efficacity in a method that might restore fertility long after treatment proves difficult and requires long-term follow-up with young prepubescent patients, introducing a possible delay of over 15 years to establish the degree of efficacy.

Current absence of robust data regarding efficacy could be used to justify denial of reimbursement by health insurances. However, emerging data underlines the importance of further research to pave the way for the offer of OTC to become the standard of care [33]. Even though OTC is still experimental -in all ages- it has the potential to become an established fertility preservation method in the near future [8,34]. International recommendations from a 2016 expert meeting conclude that the best candidates for OTC are prepubescent girls [35]. As for any emerging technology whose effectiveness is in the process of being established, acceptance by professional societies as no longer experimental is a key step towards increasing its offer and implementation. Another element is analysis of cost-effectiveness to determine a policy approach regarding systematic offer and public funding.

In light of the findings of this study, we argue that such assessments of OTC are urgent, since not offering it could be ethically problematic from at least four perspectives: future reproductive autonomy, equity of access, vulnerability and consent. 
1. Future reproductive autonomy: Some participants have pointed out future reproductive autonomy as an important ethical issue (Fig. 4). Barriers to fertility preservation possibly limit the future capacity to have genetically-related children, thereby limiting future reproductive autonomy and the "right to an open future" [36]. While having genetically-related children could be important to women regardless of their culture [37], the meaning of infertility varies across cultures and could present particular challenges in cultures where it can lead to stigmatization, such as in a Muslim country like Morocco [38]. This requires clinicians to take cultural values into account when respecting families' autonomous decision-making.

2. Equity of access: The cost of fertility preservation is very high, ranging from $\$ 5000$ to $\$ 30,000$, depending on what is covered (retrieval of ovarian tissue, annual cryopreservation fees, future transplantation, and future IVF) [39]. This creates a barrier to access for many young girls and raises justice and equity issues. Participants in our study noted cost as an important reason for not offering fertility preservation (Fig. 4). This result corroborates the findings of Campbell's study, which underlines the cost of fertility preservation as the most commonly reported barrier for pediatric oncology providers [40]. The issue of access can be resolved or alleviated by public funding, as in case of France and other European countries [41]. Cost-effectiveness analysis of OTC is therefore needed to inform policy decisions regarding public funding in countries that do not offer it.

3. Vulnerability: The stress caused by barriers to access may exacerbate the vulnerability of young girls and their parents at a time when they are coping with a life-threatening diagnosis and impending cancer treatment [42]. This vulnerability could also impact childhood cancer survivors when they have reached adulthood in case of infertility [43] knowing that they could have benefited from an already existing treatment.

4. Consent and assent: Offering OTC to all patients without financial constraints would be an important step forward, but ethical challenges also include how to present relevant information about OTC to families, considering the experimental nature of the technique and the young age of the patient. Indeed, Canadian participants highlighted consent/assent as an important ethical issue (17\%). There is therefore a need to develop guidelines for clinicians and provide them with resources that facilitate these discussions with families [44].
Towards an ethical framework for offering OTC to prepubescent girls

As highlighted by French participants, respect for future reproductive autonomy is an important ethical issue. However, practices vary considerably worldwide, depending on laws, policies, and cultural values. We argue that there is an ethical obligation to offer counselling and to discuss OTC with families of prepubescent girls in order to promote their autonomous decision-making and to allow them to consider the best interest of their daughter based on their own values.

Evaluating the best interest of a child may be a challenging task, particularly in this context, since the girl's "best interest" covers both her present interest in minimizing the risk and her future interest in promoting reproductive choice. Clinicians have an ethical obligation to inform the patient and her parents about infertility risks and fertility preservation options. Providing information will allow them to determine the child's best interest regarding fertility preservation. In the bioethical literature, a child's right to fertility preservation is recognized as a right in trust that should be protected until he or she reaches adulthood and is capable of deciding. This 'right to an open future' [45] is relevant as it interprets the best interest through the lens of the child's possible future interest in becoming a genetic parent.

Fifty percent of Moroccan participants did not recognize any ethical issue. This result underlines the lack of knowledge and awareness and the need to develop oncofertility education in Morocco. As observed by Overbeek et al. [19], lack of awareness is an important barrier, particularly in developing countries [46]. To address this issue, one option could be the establishment of centers with appropriate expertise. Indeed, to be ethically acceptable, OTC should be offered only by centers with appropriate competence to minimize the risks [35]. With time, the offer of OTC could expand to facilitate access, which requires building local expertise in the use of the technique. According to guidelines issued by the ASCO, OTC should be offered exclusively in a research setting subject to institutional review board approval [8], since benefit to the patient is not yet established [47].

Finally, guidelines for best practices in counseling are critical to an ethical offer of OTC. Discussion with a fertility specialist should ensure all relevant information is disclosed to promote informed consent and assent [44, 48]. Required general anesthesia, minor surgical procedure, need for research participation, experimental nature, and uncertainty of long-term efficacy should be discussed. An institutional program would facilitate this requirements and collaboration between the different professionals to achieve a best process of fertility preservation. Over the past few years, several programs were developed to improve fertility preservation care that had 
positive effects in patients [49-51]. The development of such programs could promote oncofertility services in countries where offer is currently insufficient, such as Morocco and Canada [46].

Another interesting result relates to posthumous disposition of preserved ovarian tissue. 14,3\% of Canadian and $20 \%$ of Moroccan participants who do not offer OTC mentioned the disposition of stored tissue as an important ethical issue. In contrast, none of the French participants recognized this as an ethical issue. Indeed, in the tragic event of death, this disposition can be an exceptionally delicate matter. Considering the young age of prepubescent girls at the time that tissue is harvested and cryopreserved, it is impossible for some of them to give their assent for a complex matter such as disposition, whether for research, donation or - in particular posthumous reproductive use. The difference between the responses of Canadian and French participants could be explained by the different regulatory frameworks governing posthumous reproduction in these countries. In France, posthumous reproductive use of gametes is prohibited by law, with or without prior consent. Consequently, French providers do not see it as a concern. In Canada, written consent could be sufficient to use gametes posthumously, which could explain the recognition of providers that it could be an ethically complex and sensitive issue in the case of OTC for young girls [52]. In Morocco, posthumous insemination is prohibited [53]. Regardless of the legal framework, the dispositional of preserved ovarian tissue should be addressed in all countries during the consent process at the time of procurement and preferences should be recorded for the future.

Fertility preservation through OTC is an experimental procedure - as highlighted by a majority of the participants (Fig. 2) - and it is not a guarantee for having genetic offspring in the future [54]. Long-term risks are also not well known [55]. The future risks of reintroducing malignant cells following transplantation could be mitigated by the notion that more robust data will be available in the future, before ovarian tissue will be reimplanted. At that point, the patient will not be a minor and could make that decision for herself.

\section{Limitations}

The main limitation of this study is that it provides only the views of pediatric hematologists/oncologists and from only three countries. It may be useful to further explore the views of patients and their families, as well as practices in additional countries. This study also focuses only on fertility preservation through OTC for young girls. It may be useful to explore via a similar methodology what is offered to pubescent girls and adult women.
Concerning the limitations of the empirical methodology, the use of survey implies a result at one specific point in time and the impossibility for participants to have further information about questions when needed, this could lead to some missing data.

Finally, another limitation of our study is related to the conceptual complexity of linking normative analysis with empirical findings. While the use of empirical methods, mostly from the social sciences, has considerably increased in bioethics $[56,57]$ there is heated debate on the appropriate ways to link this type of research with the normative work most bioethicists engage in [57-59]. "Empirical research attempts to describe the social world as it is, while normative research seeks to describe how the world ought to be." [60]. Clearly, empirical research does not "generate normativity" [61]. However, normative conclusions may be supported by empirical data [62]. In our study in particular, the findings shed light on the attitudes and experiences of pediatric hematologists/oncologists and offer a starting point for an ethical discussion that leads to some normative conclusions. These conclusions may contribute some insight into recommendations for future policy in the area of oncofertility. Indeed, since normatively patients and parents have a right to know their options, and empirically our survey shows many pediatric hematologists/oncologists do not offer or discuss fertility preservation, we need to promote the offer to meet normative requirements.

\section{Conclusions}

The results of this study show tremendous diversity in the provision of OTC across France, Canada and Morocco and show that its offer is correlated with legislation and funding. The current reality, in which this technology is often not offered to and not discussed with families, raises ethical issues related to justice and equity of access, as well as informed consent and respect for future reproductive autonomy and the child's right to an open future. Clinical guidelines should support and promote the offer and discussion of fertility preservation with children and parents. Moreover, this study shows that legal frameworks and public funding can be effective in implementing oncofertility programs.

Our findings call for further empirical studies, such as in-depth interviews to explore the needs and concerns of young girls, their families, as well as those of health professionals. Cost-effectiveness analysis is required to inform policy decisions about public funding of OTC to facilitate the implementation of the technique and reduce inequity of access. Further ethical analysis is required to consider the implications of this revolutionary technology for reproductive rights and future reproductive autonomy. 


\section{Supplementary information}

Supplementary information accompanies this paper at https://doi.org/10. 1186/s12910-020-00466-6.

\section{Additional file 1}

\section{Abbreviation}

OTC: Ovarian Tissue Cryopreservation

\section{Acknowledgements}

We are grateful to all the participants for their contribution and we would like to thank Prof. Mohamed El Khorassani and the Réseau Mère-Enfant de la Francophonie, Dr. Leah C. Young and the "C17 Council, Canadian Centers Battling Cancer and Blood Disorders in Children", the "French National Cancer Institute" and the "Moroccan Society of Pediatric Hematology and Oncology" for invaluable assistance in locating pediatric hematologists/ oncologists. The authors would like to thank Charles Dupras for his comments on the questionnaire, Stanislav Birko for his assistance with the software package SPSS 20.0 and editors and reviewers for their comments. We thank the Centre de recherche en santé publique (CReSP) for financial support to cover open access publication fees.

\section{Authors' contributions}

AOA designed the study, acquired and analysed the data, wrote the article, revised and finalized it. VR contributed to the design and analysis of data, revised the article critically and gave final approval of the version to be published. LH and MG contributed to the analysis of data and the editing of the manuscript and gave final approval of the version to be published.

\section{Authors' information}

Aliya Oulaya Affdal is Doctoral Candidate, Bioethics Program, Department of Social and Preventive Medicine, School of Public Health, University of Montreal, Canada; and Scientific Director of the Canadian Journal of Bioethics/Revue canadienne de bioéthique.

Michael Grynberg is Professor and Obstetrician gynaecologist, Department of Reproductive Medicine \& Fertility Preservation, Hôpital Antoine Beclere, Clamart, France; Université Paris Saclay, France.

Laila Hessissen is Professor and Pediatric hematologist/oncologist, Pediatric Hematology and Oncology Center, Rabat, Morocco. Vardit Ravitsky is Associate Professor, Bioethics Program, Department of Social and Preventive Medicine, School of Public Health, University of Montreal, Canada; Director of Ethics and Health, Center for Research on Ethics; and President of the International Association of Bioethics.

\section{Funding}

This study was funded by the Réseau Mère-Enfant de la Francophonie. The organization had no role in the design, collection, analysis and interpretation of data, implementation or reporting of the results of this study, nor did they commission it, or make suggestions for the submission of the findings.

\section{Availability of data and materials}

The datasets used and/or analysed during the current study are available from the corresponding author on reasonable request.

\section{Ethics approval and consent to participate}

We received ethics approval for the study from the institutional review board "Comité d'éthique de la recherche en santé" of the University of Montréal in Canada (\#15-131-CERES-D). The Ethics Committee of Ibn Sina University Hospital Rabat Centre in Morocco and the Ethics Committee "CPP IDF IV" at the hospital Saint Louis in Paris waived the necessity for ethical approval because the research was not a biomedical research related to health or medical issues and an ethical approval was already obtained in Canada. Following good ethical practice in research, we aimed to meet the expectation that participants be fully informed of the processes and outcomes, and that participation be entirely voluntary. Participants were informed that completing and returning the questionnaire constituted consent to participate in the study.

\section{Consent for publication}

Not applicable.

\section{Competing interests}

The authors declare that they have no competing interests.

\section{Author details}

${ }^{1}$ Bioethics Program, Department of Social and Preventive Medicine, School of Public Health, University of Montreal, Montréal, Québec, Canada. ${ }^{2}$ Centre de Recherche en Santé Publique, Montreal, Québec, Canada. ${ }^{3}$ Department of Reproductive Medicine \& Fertility Preservation, Hôpital Antoine Beclere, Clamart, France; Université Paris Saclay, Clamart, France. ${ }^{4}$ Pediatric Hematology and Oncology Center, Mohamed V University, Rabat, Morocco.

Received: 25 January 2019 Accepted: 9 March 2020

Published online: 03 April 2020

\section{References}

1. Winkler-Crepaz K, Ayuandari S, Ziehr SC, Hofer S, Wildt L. Fertility preservation in cancer survivors. Minerva Endocrinol. 2015;40(2):105-18.

2. Knopman JM, Papadopoulos EB, Grifo JA, Fino ME, Noyes N. Surviving childhood and reproductive-age malignancy: effects on fertility and future parenthood. Lancet Oncol. 2010;11(5):490-8. https://doi.org/10.1016/S14702045(09)70317-1.

3. Essig S, von der Weid NX, Strippoli MP, Rebholz CE, Michel G, Rueegg CS, et al. Health-related quality of life in long-term survivors of relapsed childhood acute lymphoblastic leukemia. PLoS One. 2012;7(5):e38015. https://doi.org/10.1371/journal.pone.0038015.

4. Lopategui DM, Yechieli R, Ramasamy R. Oncofertility in sarcoma patients. Transl Androl Urol. 2017;6(5):951-8. https://doi.org/10.21037/tau.2017.07.03.

5. Mertes H. Let's not forget that many prepubertal girls do have other options besides ovarian tissue cryopreservation. Hum Reprod. 2015;30(9): 2011-3. https://doi.org/10.1093/humrep/dev176.

6. Fernbach A, Lockart B, Armus CL, Bashore LM, Levine J, Kroon L, et al. Evidence-based recommendations for fertility preservation options for inclusion in treatment protocols for pediatric and adolescent patients diagnosed with cancer. J Pediatr Oncol Nurs. 2014;31(4):211-22. https://doi. org/10.1177/1043454214532025.

7. Coccia PF, Altman J, Bhatia S, Borinstein SC, Flynn J, George S, et al. Adolescent and young adult oncology. Clinical practice guidelines in oncology. J Natl Comprehens Cancer Netw. 2012;10(9):1112-50.

8. Oktay K, Harvey BE, Partridge AH, Quinn GP, Reinecke J, Taylor HS, et al. Fertility preservation in patients with cancer: ASCO clinical practice guideline update. J Clin Oncol. 2018:JCO2018781914. https://doi.org/10. 1200/JCO.2018.78.1914.

9. Anderson RA, Wallace W, Hamish B, Telfer EE. Ovarian tissue cryopreservation for fertility preservation: clinical and research perspectives. Human Reprod Open. 2017;29(1). https://doi.org/10.1093/hropen/hox001.

10. Demeestere I, Simon P, Dedeken L, Moffa F, Tsepelidis S, Brachet C, et al. Live birth after autograft of ovarian tissue cryopreserved during childhood. Hum Reprod. 2015:30(9):2107-9. https://doi.org/10.1093/humrep/dev128.

11. Donnez J, Dolmans MM. Fertility preservation in women. N Engl J Med. 2017;377(17):1657-65. https://doi.org/10.1056/NEJMra1614676.

12. Loren AW, Brazauskas R, Chow EJ, Gilleece M, Halter J, Jacobsohn DA, et al. Physician perceptions and practice patterns regarding fertility preservation in hematopoietic cell transplant recipients. Bone Marrow Transplant. 2013; 48(8):1091-7. https://doi.org/10.1038/bmt.2013.13.

13. Vadaparampil S, Quinn G, King L, Wilson C, Nieder M. Barriers to fertility preservation among pediatric oncologists. Patient Educ Couns. 2008;72(3): 402-10. https://doi.org/10.1016/j.pec.2008.05.013.

14. Goodwin T, Elizabeth Oosterhuis B, Kiernan M, Hudson MM, Dahl GV. Attitudes and practices of pediatric oncology providers regarding fertility issues. Pediatr Blood Cancer. 2007;48(1):80-5. https://doi.org/10.1002/pbc. 20814.

15. Adams E, Hill E, Watson E. Fertility preservation in cancer survivors: a national survey of oncologists' current knowledge, practice and attitudes. Br J Cancer. 2013;108(8):1602-15. https://doi.org/10.1038/bjc. 2013.139.

16. Armuand GM, Nilsson J, Rodriguez-Wallberg KA, Malmros J, Arvidson J, Lampic C, et al. Physicians' self-reported practice behaviour regarding fertility-related discussions in paediatric oncology in Sweden. Psychooncology. 2017;26(10):1684-90. https://doi.org/10.1002/pon.4507.

17. Diesch T, von der Weid NX, Szinnai G, Schaedelin S, De Geyter C, Rovo A, et al. Fertility preservation in pediatric and adolescent cancer patients in 
Switzerland: a qualitative cross-sectional survey. Cancer Epidemiol. 2016;44 141-6. https://doi.org/10.1016/j.canep.2016.08.013.

18. Terenziani M, Spinelli M, Jankovic M, Bardi E, Hjorth L, Haupt R, et al. Practices of pediatric oncology and hematology providers regarding fertility issues: a European survey. Pediatr Blood Cancer. 2014;61(11):2054-8. https:// doi.org/10.1002/pbc.25163.

19. Overbeek A, van den Berg M, Louwe L, Wendel E, ter Kuile M, Kaspers G, et al. Practice, attitude and knowledge of Dutch paediatric oncologists regarding female fertility. Neth J Med. 2014;72(5):264-70.

20. Loi no 2004-800 du 6 août 2004 relative à la bioéthique, (2004).

21. INCA. Plan cancer 2014-2019; 2014. http://www.e-cancer.fr/Expertises-etpublications/Catalogue-des-publications/Summary-Plan-cancer-2014-2019.

22. INSERM. Techniques de préservation de la fertilité: Institut National de la Santé et de la Recherche Médicale; 2018. https:/www.inserm.fr/informationen-sante/dossiers-information/techniques-preservation-fertilite.

23. Legis-Quebec. Regulation respecting the application of the health insurance act Loi 20 section XII.2, chapitre A-29, r. 5; 2015.

24. Rendtorff JD. Basic ethical principles in European bioethics and biolaw: autonomy, dignity, integrity and vulnerability--towards a foundation of bioethics and biolaw. Med Health Care Philos. 2002;5(3):235-44.

25. Andorno R. Human dignity and human rights as a common ground for a global bioethics. J Med Philos. 2009;34(3):223-40. https://doi.org/10.1093/ jmp/jhp023.

26. Beauchamp TL, Childress JF. Principles of biomedical ethics. 7th ed. New York: Oxford University Press; 2013.

27. Ruof MC. Vulnerability, vulnerable populations, and policy. Kennedy Inst Ethics J. 2004;14(4):411-25

28. Oktay K, Karlikaya G. Ovarian function after transplantation of frozen, banked autologous ovarian tissue. N Engl J Med. 2000;342(25):1919. https://doi.org/ 10.1056/NEJM200006223422516.

29. Gellert SE, Pors SE, Kristensen SG, Bay-Bjorn AM, Ernst E, Yding AC. Transplantation of frozen-thawed ovarian tissue: an update on worldwide activity published in peer-reviewed papers and on the Danish cohort. J Assist Reprod Genet. 2018;35(4):561-70. https://doi.org/10.1007/s10815-0181144-2.

30. Poirot C, Abirached F, Prades M, Coussieu C, Bernaudin F, Piver P. Induction of puberty by autograft of cryopreserved ovarian tissue. Lancet. 2012; 379(9815):588. https://doi.org/10.1016/S0140-6736(11)61781-9.

31. Ernst E, Kjaersgaard M, Birkebaek NH, Clausen N, Andersen CY. Case report: stimulation of puberty in a girl with chemo- and radiation therapy induced ovarian failure by transplantation of a small part of her frozen/thawed ovarian tissue. Eur J Cancer. 2013;49(4):911-4. https://doi.org/10.1016/j.ejca. 2012.09.028

32. Lantsberg D, Farhi A, Zaslavsky-Paltiel I, Silverman BG, Lerner-Geva L, Orvieto R. Deliveries following fertility preservation by ovarian tissue cryopreservation without autotransplantation-what should be expected? J Assist Reprod Genet. 2019;36(2):335-40. https://doi.org/10.1007/s10815-0181341-z.

33. Ladanyi C, Mor A, Christianson MS, Dhillon N, Segars JH. Recent advances in the field of ovarian tissue cryopreservation and opportunities for research. J Assist Reprod Genet. 2017;34(6):709-22. https://doi.org/10.1007/s10815-0170899-1.

34. Arian $\mathrm{SE}$, Flyckt RL, Herman $\mathrm{R}$, Erfani $\mathrm{H}$, Falcone T. Fertility preservation in pediatric female cancer patients. Fertil Steril. 2018;109(5):941. https://doi.org/ 10.1016/j.fertnstert.2018.02.112

35. Lambertini M, Del Mastro L, Pescio MC, Andersen CY, Azim HA Jr, Peccatori FA, et al. Cancer and fertility preservation: international recommendations from an expert meeting. BMC Med. 2016;14:1. https://doi.org/10.1186/ s12916-015-0545-7.

36. Michaeli J, Weintraub M, Gross E, Ginosar Y, Ravitsky V, Eizenman E, et al. Fertility preservation in girls. Obstet Gynecol Int. 2012;2012:139193. https:// doi.org/10.1155/2012/139193.

37. Rulli T. Preferring a genetically-related child. J Moral Philos. 2014;1 (30):669-98.

38. Serour GI. Islamic perspectives in human reproduction. Reprod Biomed Online. 2008;17(Suppl 3):34-8.

39. Levine J, Canada A, Stern CJ. Fertility preservation in adolescents and young adults with cancer. J Clin Oncol. 2010;28(32):4831-41. https://doi.org/10. 1200/JCO.2009.22.8312

40. Campbell JE, Assanasen C, Robinson RD, Knudtson JF. Fertility preservation counseling for pediatric and adolescent cancer patients. J Adolesc Young Adult Oncol. 2016;5(1):58-63. https://doi.org/10.1089/jayao.2015.0040.
41. Diesch T, Rovo A, von der Weid N, Faraci M, Pillon M, Dalissier A, et al. Fertility preservation practices in pediatric and adolescent cancer patients undergoing HSCT in Europe: a population-based survey. Bone Marrow Transplant. 2017;52(7):1022-8. https://doi.org/10.1038/bmt.2016.363.

42. Wallace WH, Kelsey TW, Anderson RA. Fertility preservation in pre-pubertal girls with cancer: the role of ovarian tissue cryopreservation. Fertil Steril. 2016;105(1):6-12. https://doi.org/10.1016/j.fertnstert.2015.11.041.

43. Malin M, Hemmink E, Raikkonen O, Sihvo S, Perala ML. What do women want? Women's experiences of infertility treatment. Soc Sci Med. 2001;53(1): 123-33. https://doi.org/10.1016/s0277-9536(00)00317-8.

44. Barlevy D, Elger BS, Wangmo T, Ravitsky V. Adolescent oncofertility discussions: recommendations from a systematic literature review. AJOB Empir Bioeth. 2017;8(2):106-15. https://doi.org/10.1080/23294515.2017. 1305006.

45. Feinberg J. The child's right to an open future. Whose child? : children's rights, parental authority, and state power. Totowa: Rowman and Littlefield; 1980. p. 310.

46. Salama M, Ataman L, Taha T, Azmy O, Braham M, Douik F, et al. Building Oncofertility Core competency in developing countries: experience from Egypt, Tunisia, Brazil, Peru, and Panama. J Glob Oncol. 2018;4:1-11. https:// doi.org/10.1200/JGO.17.00121.

47. Rebar RW. Social and ethical implications of fertility preservation. Fertil Steril. 2016;105(6):1449-51. https://doi.org/10.1016/j.fertnstert.2016.02.002.

48. Romao RL, Lorenzo AJ. Fertility preservation options for children and adolescents with cancer. Can Urol Assoc J. 2017;11(1-2Suppl1):S97-S102. https://doi.org/10.5489/cuaj.4410.

49. Kelvin JF, Thom B, Benedict C, Carter J, Corcoran S, Dickler MN, et al. Cancer and fertility program improves patient satisfaction with information received. J Clin Oncol. 2016;34(15):1780-6. https://doi.org/10.1200/JCO.2015. 64.5168.

50. Moravek MB, Appiah LC, Anazodo A, Burns KC, Gomez-Lobo V, Hoefgen HR, et al. Development of a pediatric fertility preservation program: a report from the pediatric initiative network of the Oncofertility consortium. J Adolesc Health. 2019;64(5):563-73. https://doi.org/10.1016/j.jadohealth.2018. 10.297 .

51. Ben-Aharon I, Abir R, Perl G, Stein J, Gilad G, Toledano H, et al. Optimizing the process of fertility preservation in pediatric female cancer patients - a multidisciplinary program. BMC Cancer. 2016;16:620. https://doi.org/10.1186/ s12885-016-2584-7.

52. Tremellen K, Savulescu J. A discussion supporting presumed consent for posthumous sperm procurement and conception. Reprod Biomed Online. 2015;30(1):6-13. https://doi.org/10.1016/j.rbmo.2014.10.001

53. Inhorn MC, Birenbaum-Carmeli D, Tremayne S, Gurtin ZB. Assisted reproduction and Middle East kinship: a regional and religious comparison. Reprod Biomed Soc Online. 2017;4:41-51. https://doi.org/10.1016/j.rbms. 2017.06.003.

54. McDougall R. The ethics of fertility preservation for Paediatric cancer patients: from offer to rebuttable presumption. Bioethics. 2015;29(9):639-45. https://doi.org/10.1111/bioe.12190

55. Carvalho BR, Kliemchen J, Woodruff TK. Ethical, moral and other aspects related to fertility preservation in cancer patients. JBRA Assist Reprod. 2017; 21(1):45-8. https://doi.org/10.5935/1518-0557.20170011.

56. Borry $P$, Schotsmans $P$, Dierickx $K$. The birth of the empirical turn in bioethics. Bioethics. 2005;19(1):49-71. https://doi.org/10.1111/j.1467-8519. 2005.00424.x.

57. Davies R, Ives J, Dunn M. A systematic review of empirical bioethics methodologies. BMC Med Ethics. 2015;16:15. https://doi.org/10.1186/s12910015-0010-3

58. Salloch S, Schildmann J, Vollmann J. Empirical research in medical ethics: how conceptual accounts on normative-empirical collaboration may improve research practice. BMC Med Ethics. 2012;13:5. https://doi.org/10. 1186/1472-6939-13-5.

59. Molewijk B, Stiggelbout AM, Otten W, Dupuis HM, Kievit J. Empirical data and moral theory. A plea for integrated empirical ethics. Med Health Care Philos. 2004;7(1):55-69. https://doi.org/10.1023/b:mhep.0000021848.75590. bo.

60. Leget C, Borry P, de Vries R. 'Nobody tosses a dwarf'' the relation between the empirical and the normative reexamined. Bioethics. 2009;23(4):226-35. https://doi.org/10.1111/j.1467-8519.2009.01711.x.

61. Strong KA, Lipworth W, Kerridge I. The strengths and limitations of empirical bioethics. J Law Med. 2010;18(2):316-9. 
62. Sugarman J, Sulmasy DP. The many methods of medical ethics. In: Sugarman J, Sulmasy DP, editors. Methods in medical ethics. 2nd ed. Washington, D.C.: Georgetown University Press; 2010. p. xiii. 353 p.

\section{Publisher's Note}

Springer Nature remains neutral with regard to jurisdictional claims in published maps and institutional affiliations.

Ready to submit your research? Choose BMC and benefit from:

- fast, convenient online submission

- thorough peer review by experienced researchers in your field

- rapid publication on acceptance

- support for research data, including large and complex data types

- gold Open Access which fosters wider collaboration and increased citations

- maximum visibility for your research: over $100 \mathrm{M}$ website views per year

At $\mathrm{BMC}$, research is always in progress. 